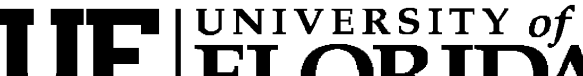 FLORIDA \\ IFAS Extension
}

ENH988

\section{Florida Native Aquatic Plants for Ornamental Water Gardens 1}

\section{Eva C. Worden and David L. Sutton ${ }^{2}$}

Water gardening is increasing in popularity in ornamental landscapes across the country.

Ornamental aquatic plants can be grown in small ponds and in containers on the patio or in the yard. Many water-tight containers of many sizes and shapes are available for displaying ornamental aquatic plants. Water gardens provide additional, attractive features to landscapes not available with terrestrial plants.

An aquatic plant palette of considerable variety is available for water gardens in Florida (Table 1). The abundance of sunshine and warm temperatures provides ideal growing conditions for many aquatic plant species.

\section{Invasive Aquatic Plants}

Caution needs to be exercised in the selection of aquatic plants for the water garden as some ornamental plants can be invasive to wetlands and other bodies of water. For example, water hyacinth (Eichhornia crassipes), in spite of its beautiful purple flower (Figure 1), is a serious weed in Lake
Okeechobee (Figure 2) and nearby waters. To avoid the introduction of plants like water hyacinth that may cause problems, consult the Florida Exotic Pest Plant Council's current list of invasive plants (available on the Internet at www.fleppc.org) prior to introducing ornamental aquatic plants in your water garden. Also, contact your local county extension agent for advice on how to avoid prohibited, invasive aquatic plants. Above all, do not discard any live plants in Florida's waterways.

\section{Characteristics of an Aquatic Plant}

Approximately $1 \%$ of all plant species live and complete their life cycle in and around water.

Saturated and flooded soils create anaerobic conditions that kill most plants. However, aquatic plants have developed anatomical and morphological adaptations that allow them to grow and thrive in these low oxygen environments.

Oxygen and carbon dioxide are critical requirements for the growth of all plants. Aquatic plants meet this requirement through the development

1. This document is ENH988, one of a series of the Environmental Horticulture Department, Florida Cooperative Extension Service, Institute of Food and Agricultural Sciences, University of Florida. Original publication date February 2005. Visit the EDIS Web Site at http://edis.ifas.ufl.edu.

2. Eva C. Worden, Assistant Professor, Environmental Horticulture; David L. Sutton, Professor, Agronomy, University of Florida, Institute of Food and Agricultural Sciences, Fort Lauderdale Research and Education Center, Fort Lauderdale, Florida, 33314.

All photographs by David L. Sutton

The use of trade names in this publication is solely for the purpose of providing specific information. UF/IFAS does not guarantee or warranty the products named, and references to them in this publication does not signify our approval to the exclusion of other products of suitable composition. 
of specialized cells called aerenchyma, which allow movement of these gases from plant parts that are in the air to those parts of the plant growing under anaerobic conditions. Aerenchyma tissue forms air spaces within the plant showing different patterns and formations depending on the plant species (Figures 3, $4,5,6$, and 7).

\section{Basic Terminology of Aquatic Plants}

Aquatic plants may be classified according to their habit of growth: marginal, floating-leaved, floating, and submerged. In water gardens, marginal and floating-leaved plants typically are used more than floating or submerged, because of their showy flowers and unique foliage.

\section{Marginal Aquatic Plants}

Marginal or emergent plants have their shoots above the water and portions of the shoot and roots below the water. Many shoreline plants fall into this category such as Alligator flag (Figures 8 and 9), and pickerelweed (Figures 10 and 11). These plants must be rooted, and they require fertilizer applied in the root zone for optimum growth.

\section{Floating-leaved Plants}

Floating-leaved plants have only their leaves floating on the surface of the water, and the remaining portions of the plant under water. Waterlilies (Figures 12 and 13) are an example. Floating-leaved plants must be rooted and fertilizer applied in the root zone for optimum growth. American lotus (Figures 14 and 15) is another plant with floating leaves. However, about half of their leaves are held above the surface of the water by erect, stout stems. American lotus and waterlilies require high amounts of fertilizer for flowering.

\section{Floating Plants}

Floating plants are not attached to the soil and float freely in the water. Plants may float on the surface like the duckweeds (Figures 16 and 17), or under the water like purple bladderwort (Figure 18). These plants receive all their nutritional needs from the water.

\section{Submerged Plants}

Submerged plants, such as eelgrass, grow completely covered with water (Figure 19). These plants are typically planted in a water garden to help provide oxygen to the water. Submerged plants receive most of their nutritional needs from the sediments in which they are growing.

\section{Books of Interest for Water Gardening}

Ledbetter, Gordon T. 1979. Water Gardens. Alphabooks, Sherborne, Dorset, England. First American edition 1980 by W.W. Norton \& Company., New York. 152 pp.

Nash, Helen and Steve Stroupe. 1998. Aquatic Plants \& Their Cultivation - A Complete Guide for Water Gardeners. Sterling Publishing Company, Inc., 387 Park Avenue South, New York, N.Y. 10016. 224 pp. (Other books by Helen Nash include:

Low-Maintenance Water Gardens, The Complete Pond Builder: Creating a Beautiful Water Garden, and The Pond Doctor: Planning \& Maintaining a Healthy Water Garden).

Paul, Anthony and Yvonne Rees. 1986. The Water Garden. Penguin Books, Viking Penguin Inc., 40 West 23rd Street, New York, N.Y. 10010. 167 pp.

Robinson, Peter. 1987. Pool and Waterside Gardening. Collingridge Books, an imprint of The Hamlyn Publishing Group Limited, Bridge House, 69 London Road, Twickenham, Middlesex, England in association with The Royal Botanic Gardens, Kew. $124 \mathrm{pp}$.

Russell, Stanley. 1985. The Stapely Book of Water Gardens. David \& Charles Inc., North Pomfret, Vermont 05053. 180 pp.

Slocus, Perry D. and Peter Robinson with Frances Perry. 1996. Water Gardening: Water Lilies and Lotuses. Timber Press, Inc., The Haseltine Building, 133 S.W. Second Avenue, Suite 450, Portland, Oregon 97204. 322 pp. 


\section{Retail Distributers}

While there exists great variety in ornamental aquatic plants that may be used for Florida water gardens, currently there are few retail outlets for this plant material. The listing below is provided to assist in locating the plants listed herein. Use of company names does not imply endorsement of their products or exclusion of similar ones not mentioned.

\section{Mail-Order Catalogues and Internet Sites}

Lilypons Water Gardens

P.O. Box 10

Buckeystown, MD 21717-0010

(800) 999-5459

www.lilypons.com

Paradise Water Gardens

14 May Street

Whitman, MA 02382

(800) 955-0161

www.paradisewatergardens.com

Waterford Gardens

74 E. Allendale Road

Saddle River, NJ 07458

(201) 327-0721

www.waterford-gardens.com

Kraus Tropicals, Inc.

P.O. Box 2748

Riverview, Florida 33569
(800) 577-9135

Dania Beach Water Gardens and Gifts

400 S. Federal Highway

Dania Beach, Florida 33004

(954) 920-0321

Figures

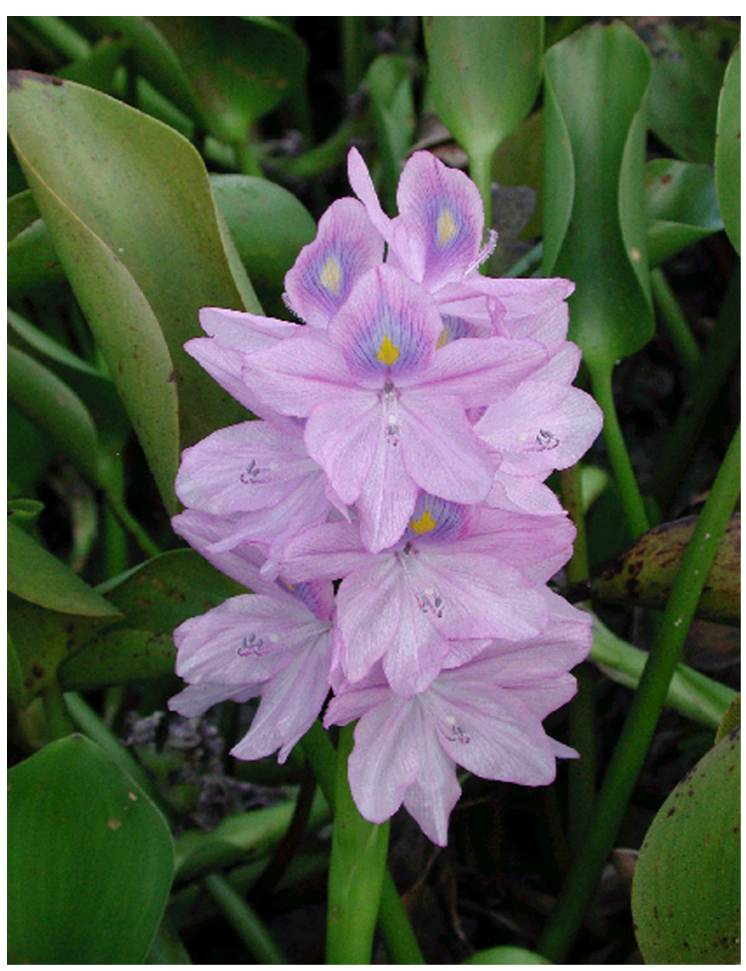

Figure 1. Flowers of water hyacinth. Credits: 


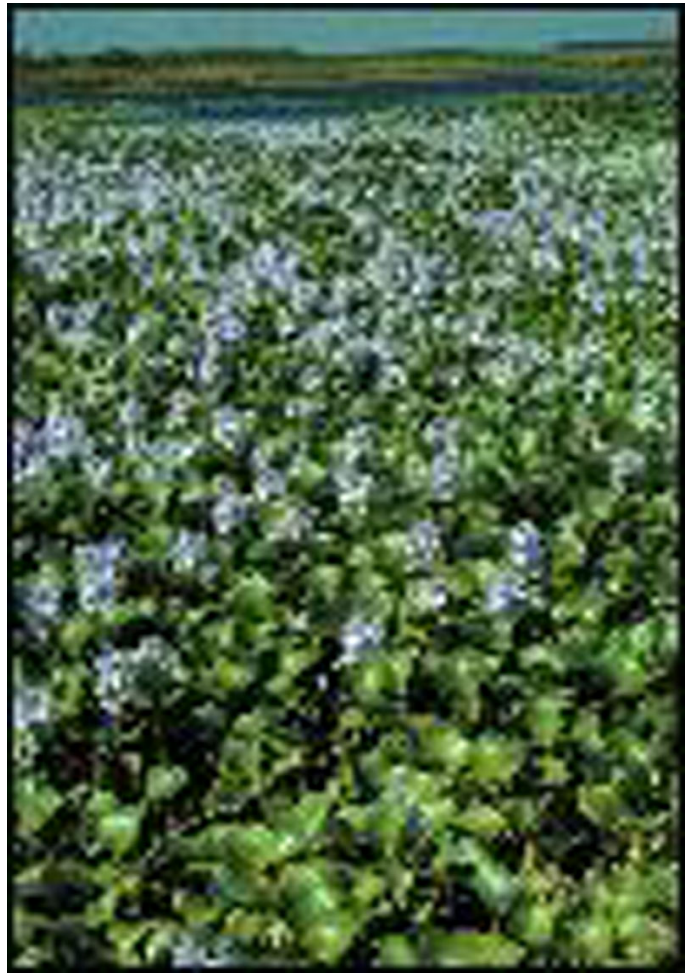

Figure 2. Overgrowth of the water hyacinth in Lake Okeechobee.

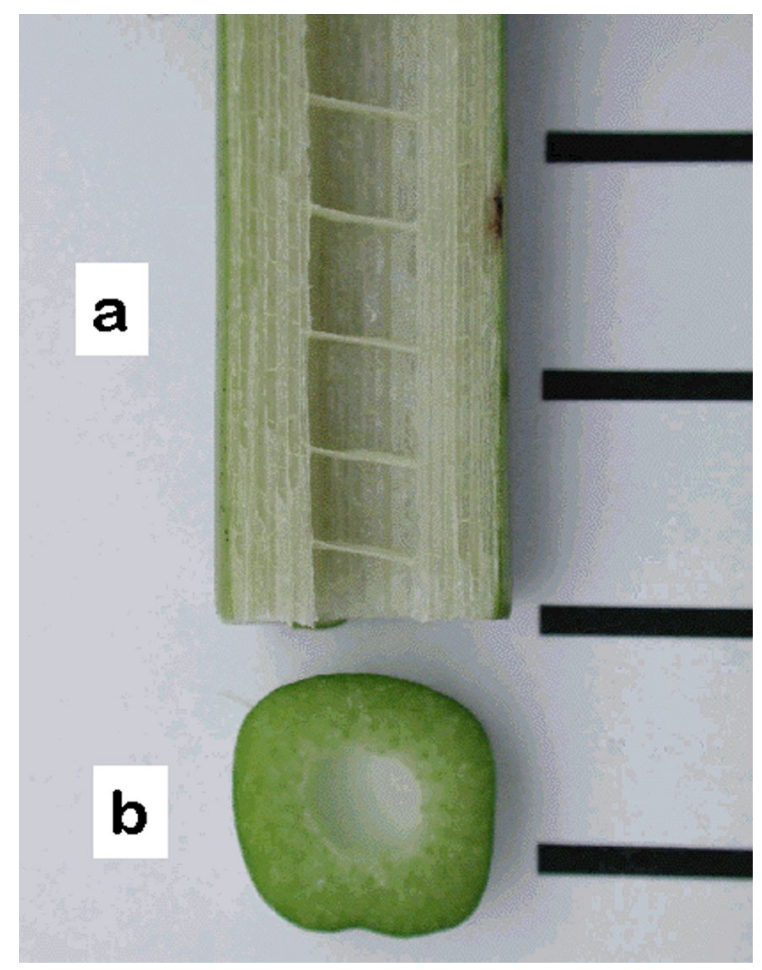

Figure 3. Air chamber in a pickerelweed stem (a) longitudinally and (b) cross-section. Credits:

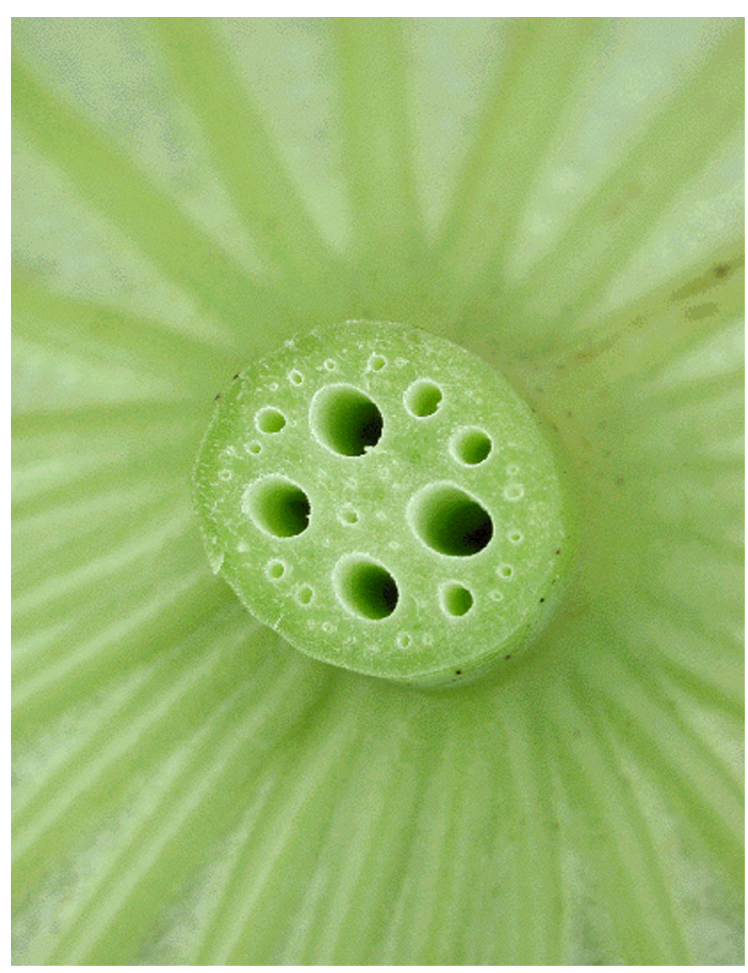

Figure 4. American lotus (Nelumbo lutea)showing the air channels in a cross-section of petiole cut just below the under-surface of a floating leaf. Credits:

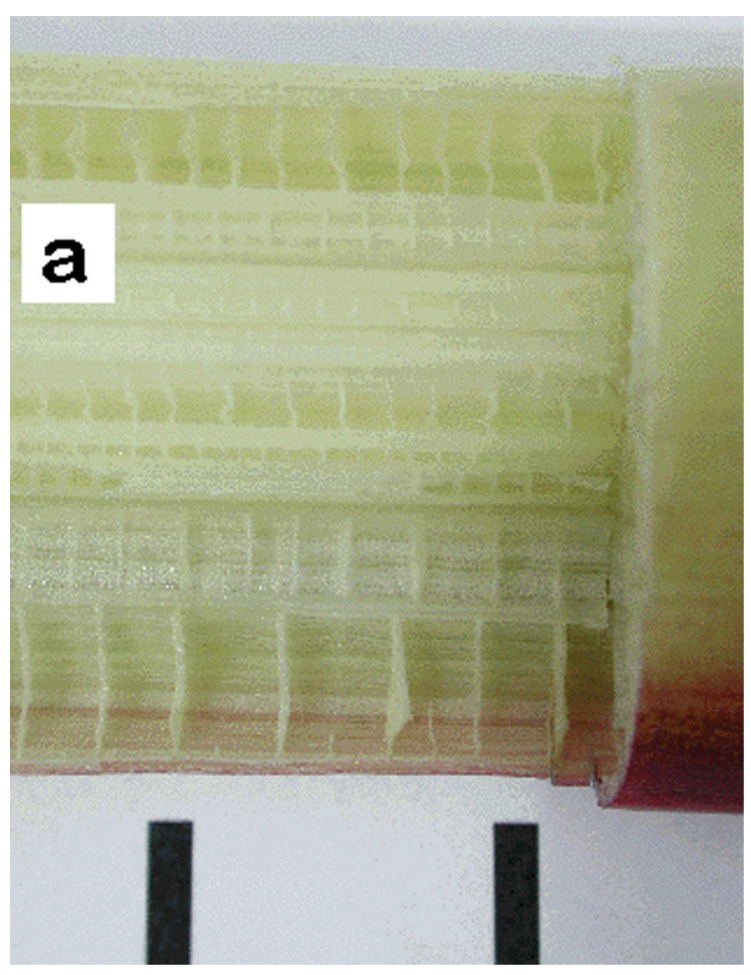

Figure 6. Stem of alligator flag (Thalia geniculata) showing the air spaces in longitudinal view . The bars are $1 \mathrm{~cm}$ apart. 


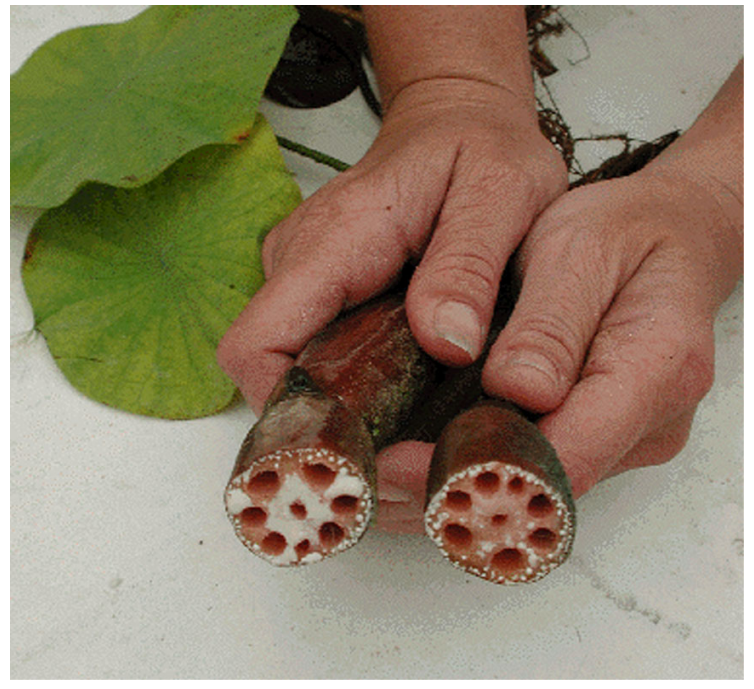

Figure 5. American lotus (Nelumbo lutea)showing the air channels in rhizomes.

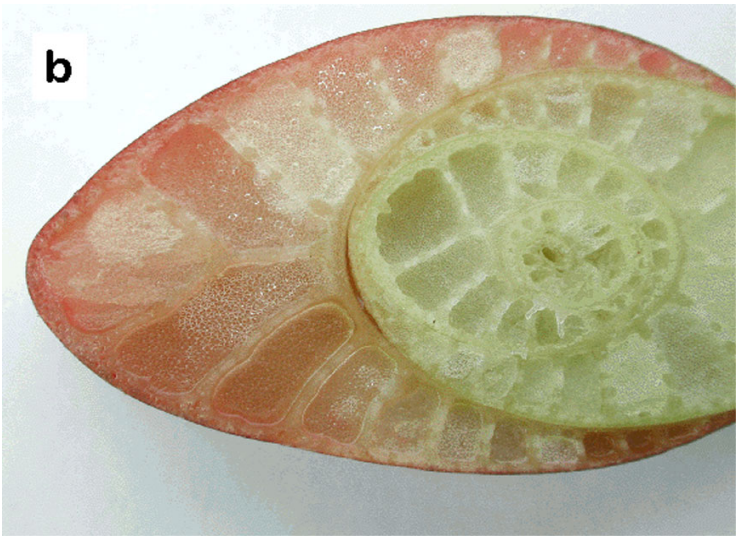

Figure 7. Stem of alligator flag (Thalia geniculata) showing the air spaces in a cross section.

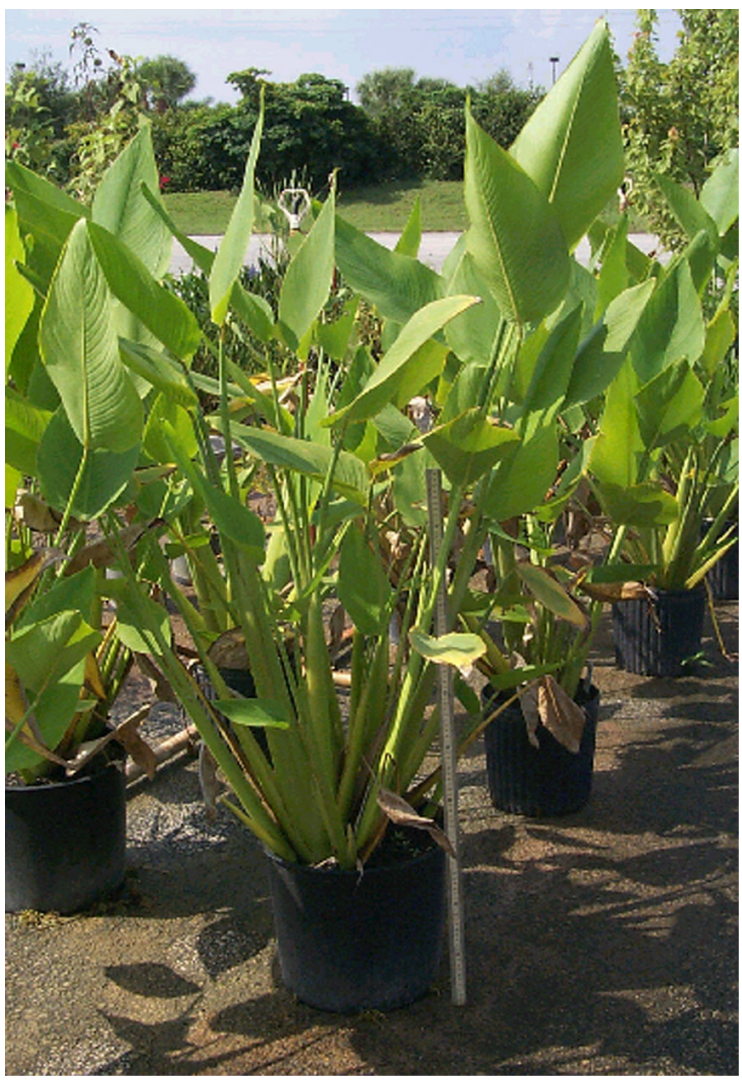

Figure 8. Alligator flag in culture.

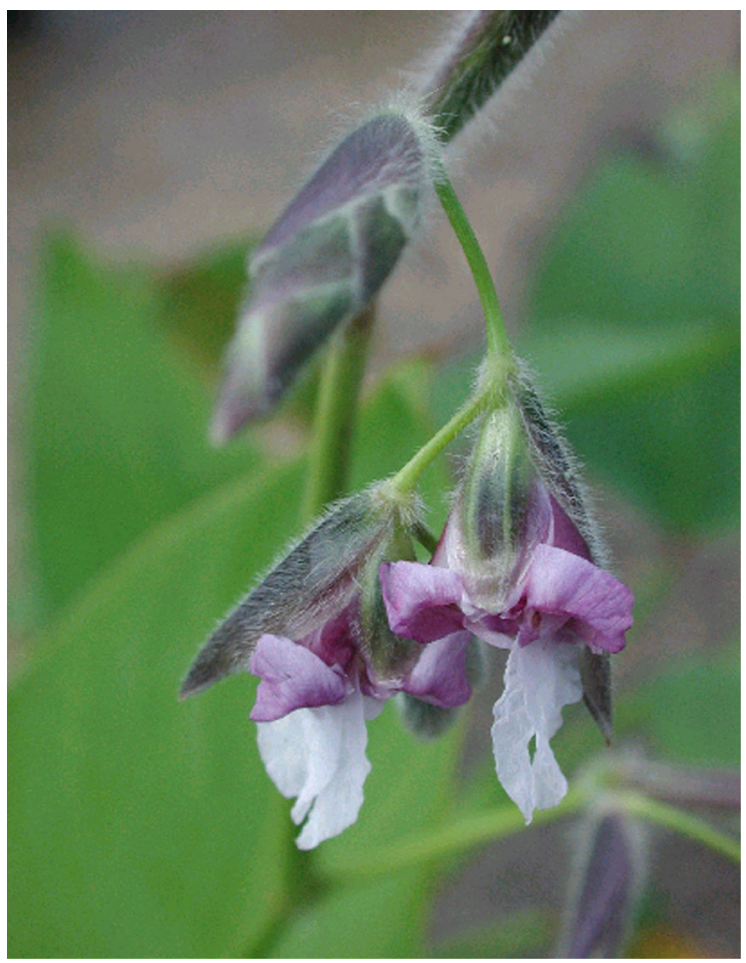

Figure 9. Flowers of alligator flag are small in relation to the large leaves of this plant. 


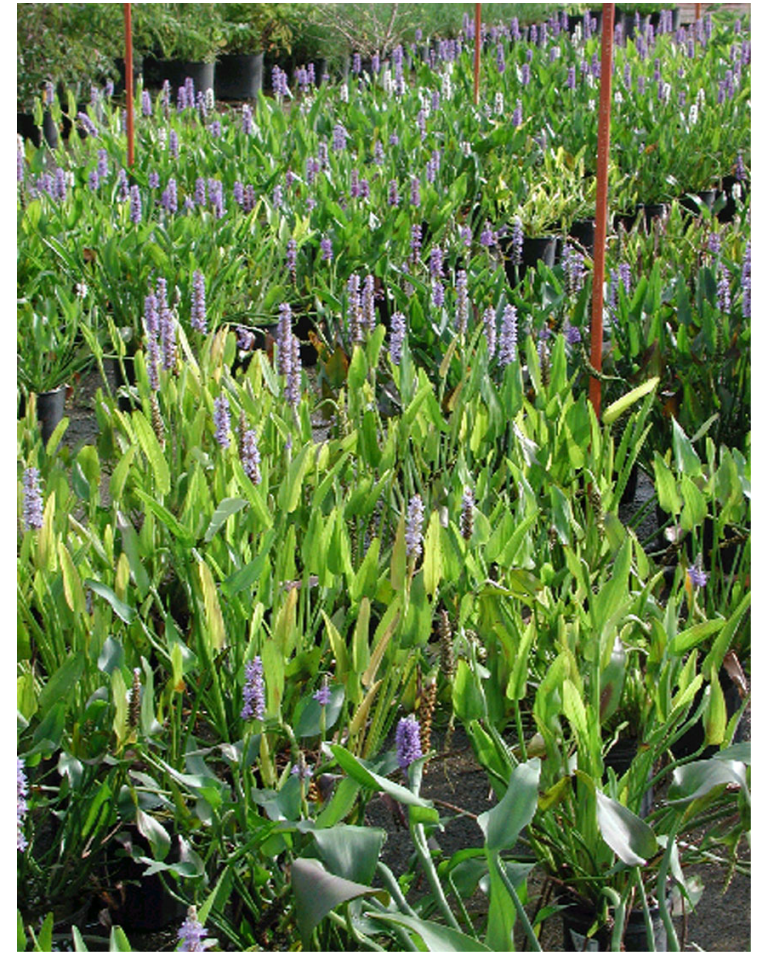

Figure 10. Pickerel weed in culture.

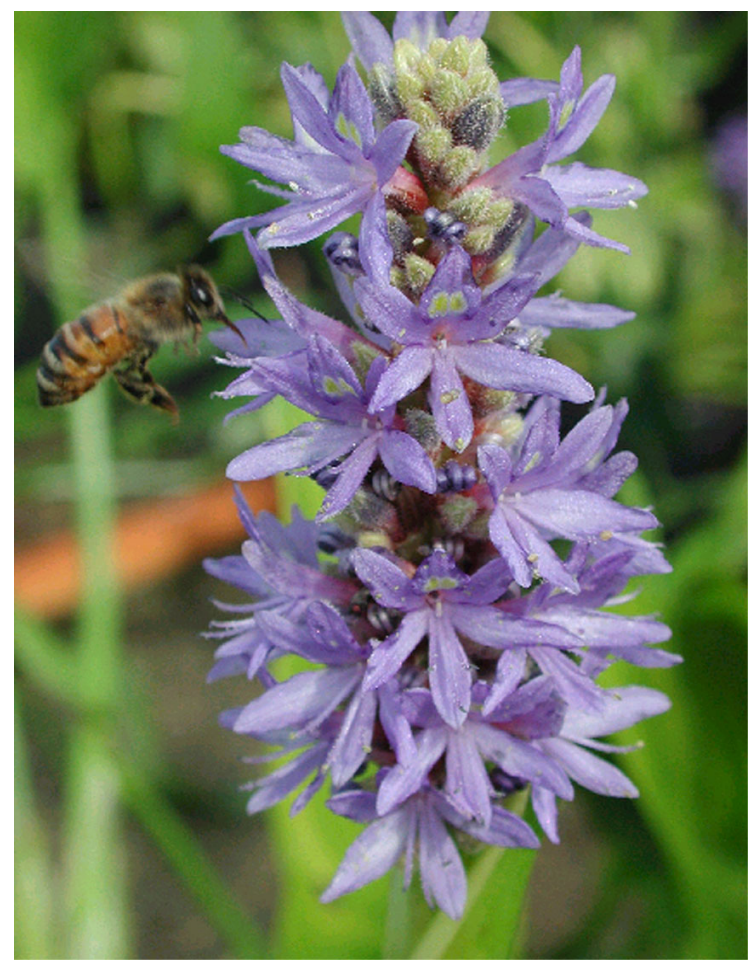

Figure 11. Honeybees are frequent pollinators of pickerel weed flowers.

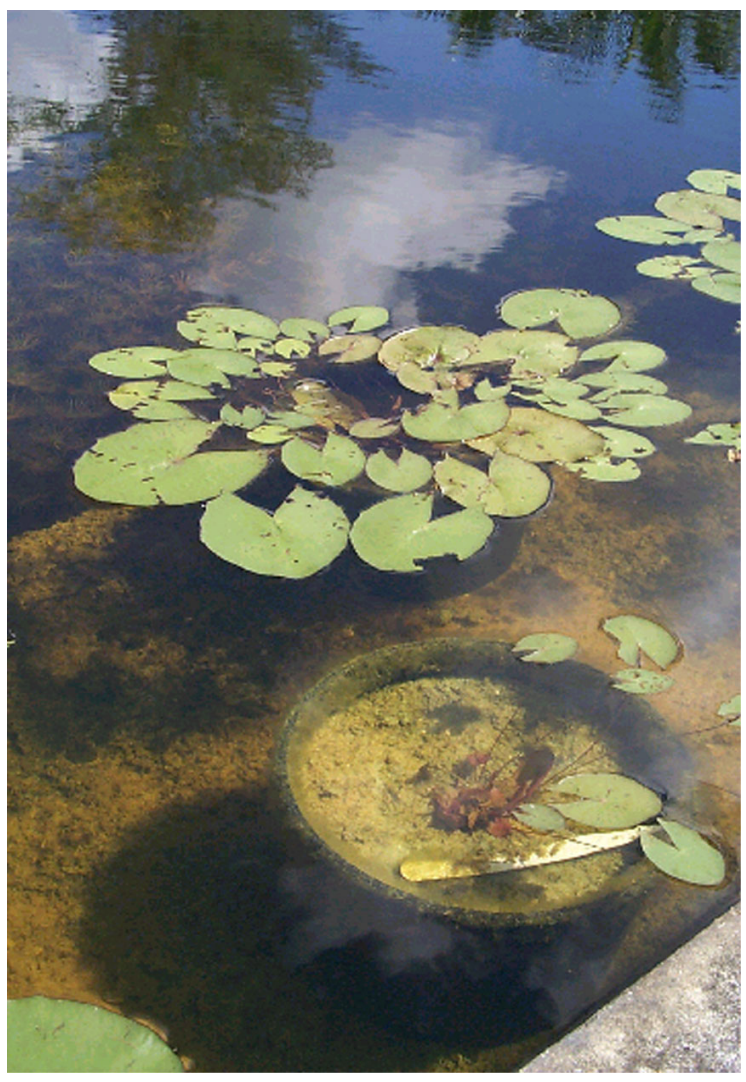

Figure 12. Young water lily plants in culture, with their leaves floating on the surface, attached by long stems to the rhizome growing in the soil below the surface.

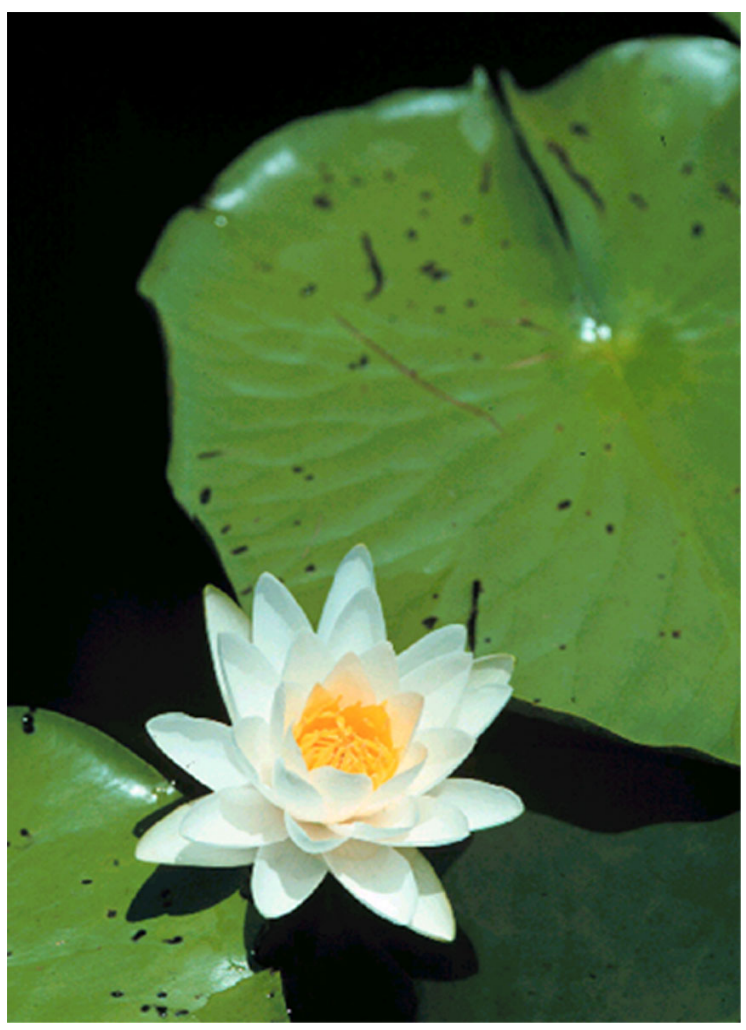

Figure 13. Flower of fragrant water lily plants growing in Lake Okeechobee. 


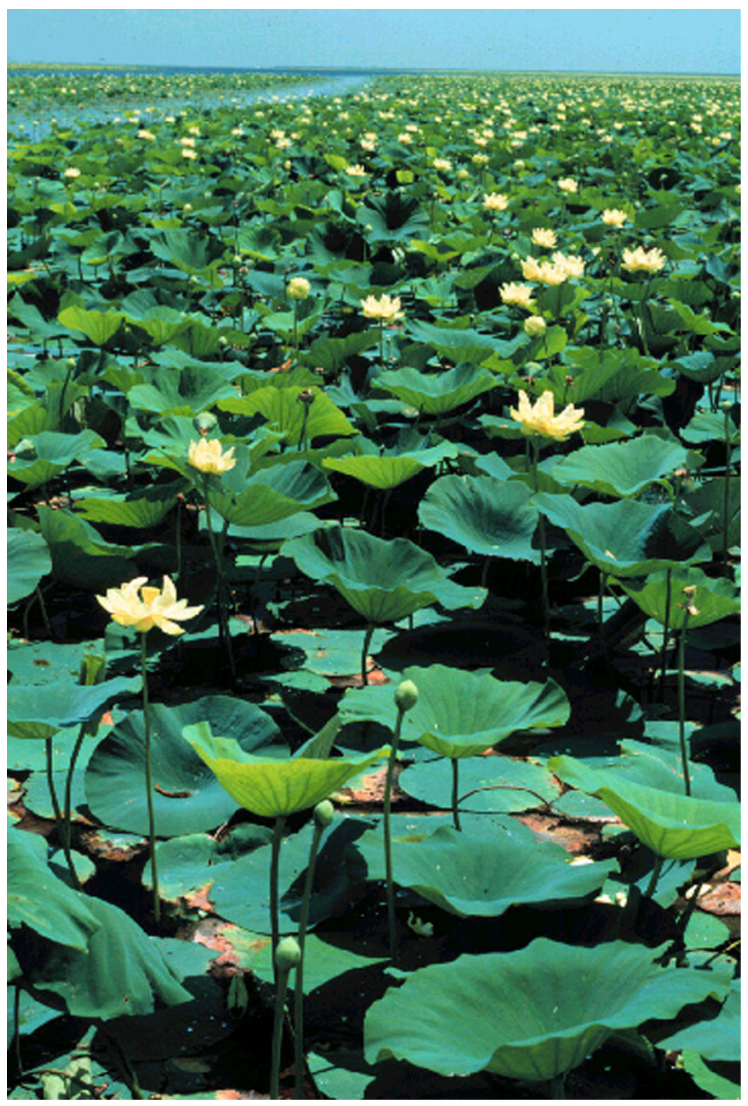

Figure 14. American lotus growing in Lake Okeechobee.

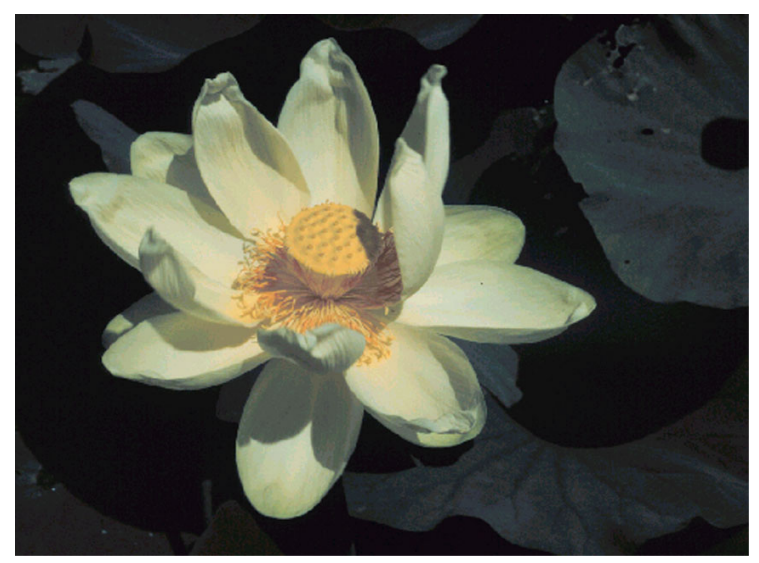

Figure 15. Flowers of lotus are large and showy. Hybrids with flowers of various colors are now available from many aquatic plant nurseries.

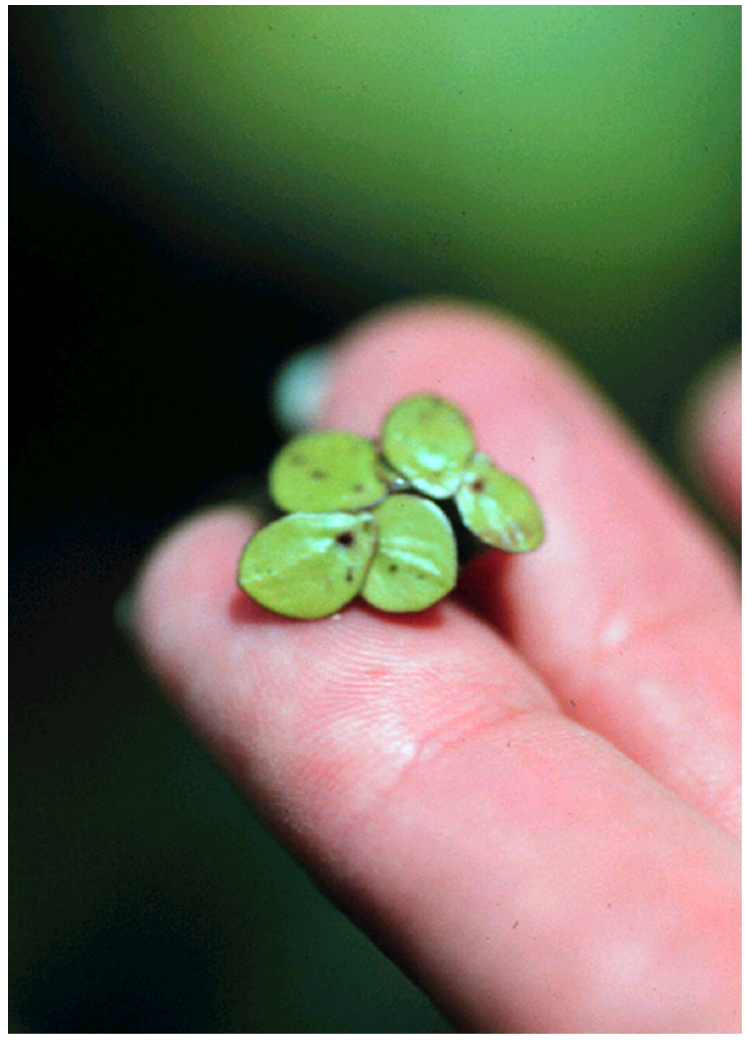

Figure 16. Members of the duckweed family contain the smallest flowering plants in the world. The plants shown here are called "giant duckweed" because they are the largest in the family.

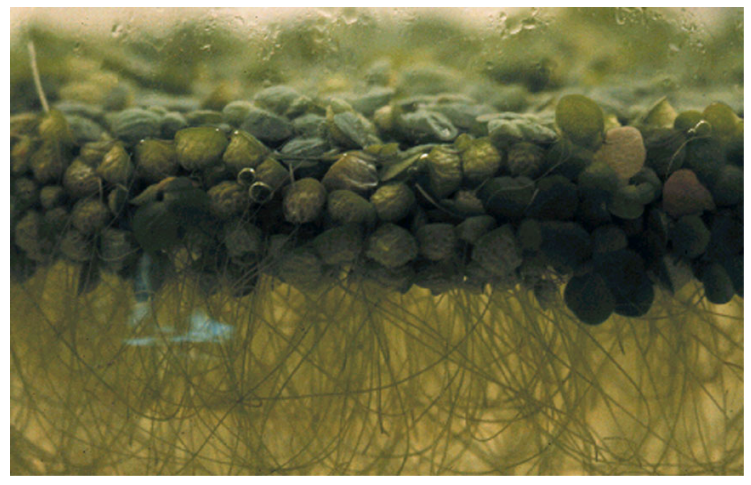

Figure 17. Roots on the duckweed plants function to help keep plants upright as they float on the surface. 


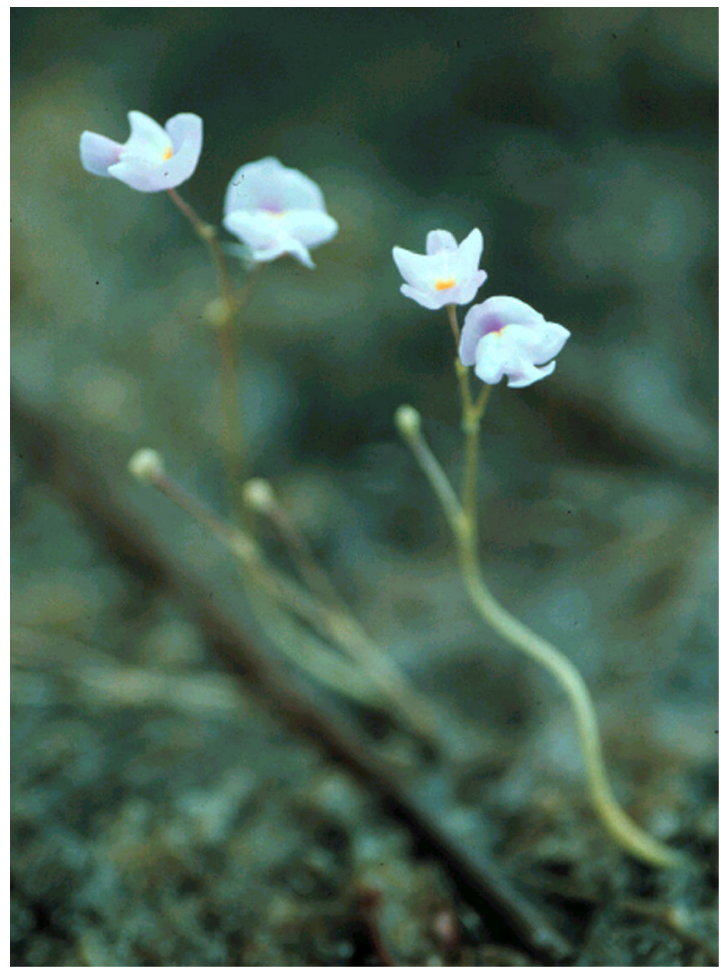

Figure 18. Flowers of the purple bladderwort extending above the surface of Lake Okeechobee.

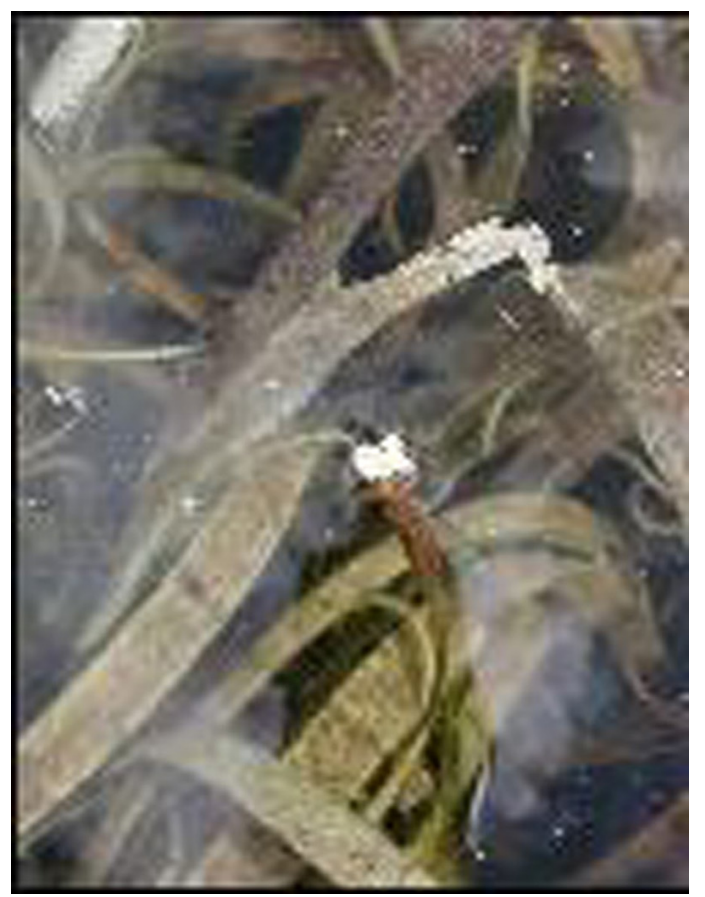

Figure 19. Dense submerged growth of eelgrass. Leaves are just under the water surface, and a flower extends above the water. 


\begin{tabular}{|c|c|c|c|c|c|c|c|c|}
\hline 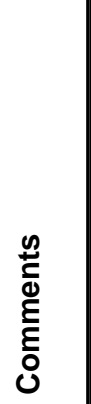 & 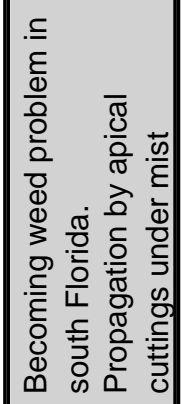 & 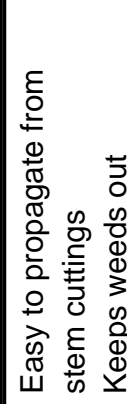 & 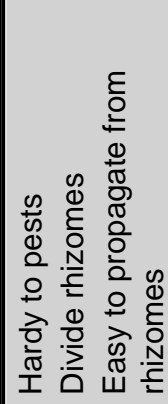 & 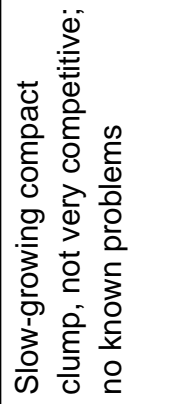 & 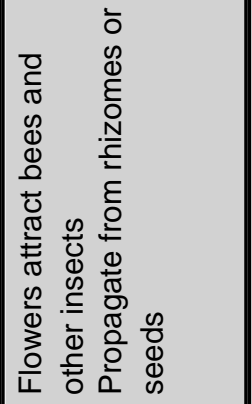 & 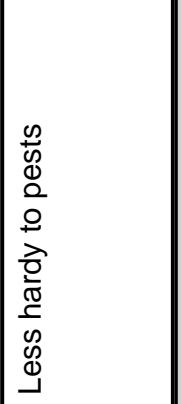 & & 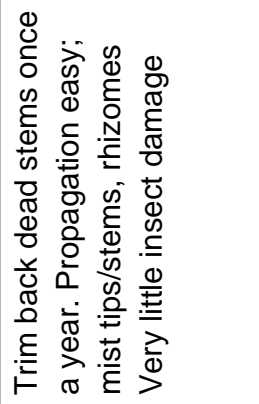 \\
\hline $\begin{array}{l}\frac{5}{5} \\
\frac{1}{4} \\
\frac{5}{0} \\
\frac{5}{20} \\
\frac{0}{4}\end{array}$ & 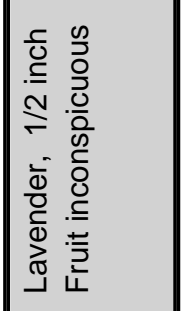 & 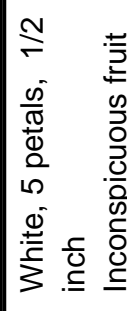 & 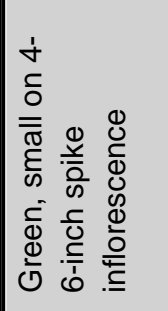 & 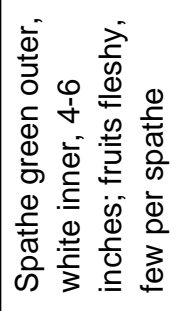 & 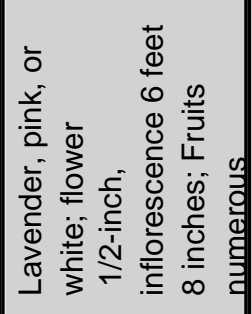 & 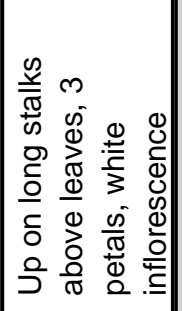 & 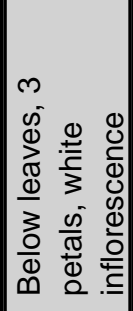 & 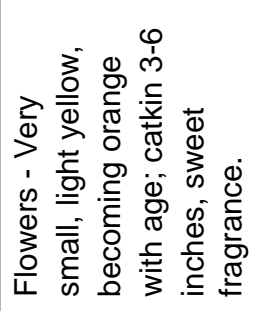 \\
\hline 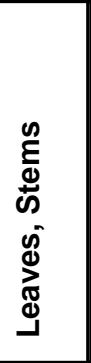 & 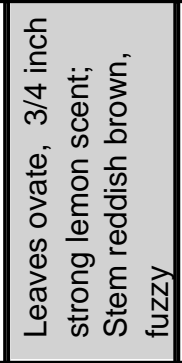 & 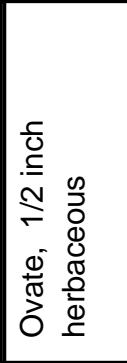 & 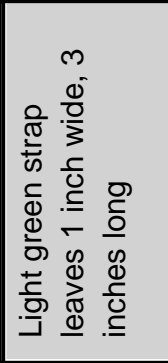 & 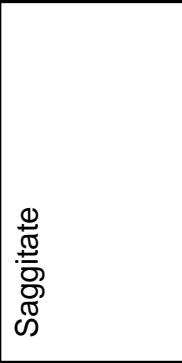 & 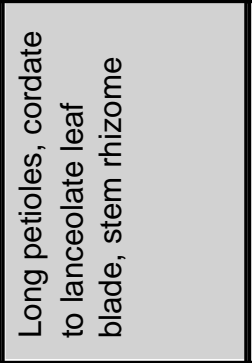 & 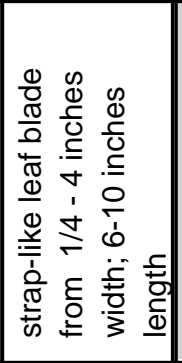 & 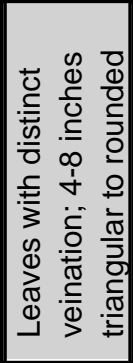 & 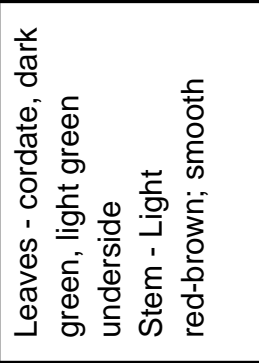 \\
\hline$\frac{\mathbb{N}}{\omega}$ & 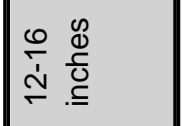 & $\sim \stackrel{\mathscr{\Phi}}{\frac{\mathscr{E}}{0}}$ & 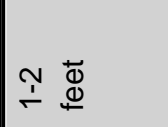 & $\begin{array}{l}\stackrel{+}{\Phi} \\
\stackrel{\Phi}{N} \\
\sim\end{array}$ & ले & 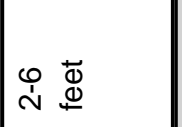 & 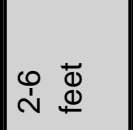 & 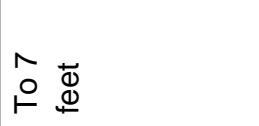 \\
\hline $\begin{array}{l}\xi \\
\text { 훈 }\end{array}$ & 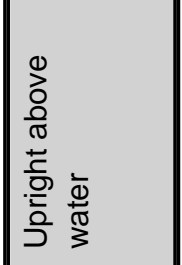 & 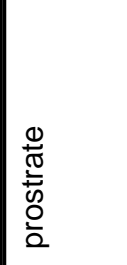 & 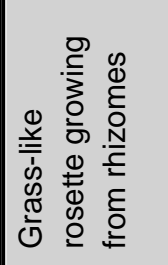 & 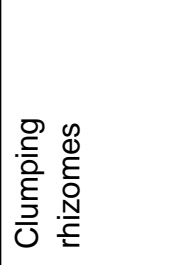 & 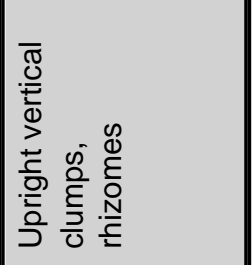 & 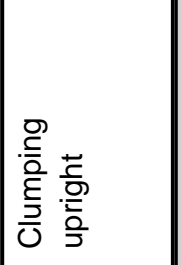 & 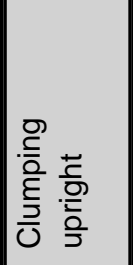 & 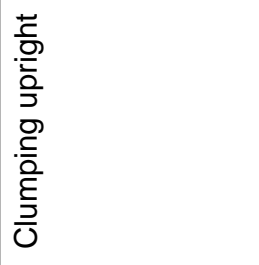 \\
\hline 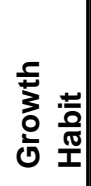 & 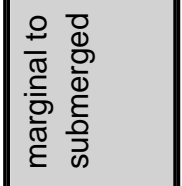 & $\begin{array}{l}\overline{0} \\
. \overline{5} \\
\frac{\overline{0}}{\tilde{\sigma}} \\
\varepsilon\end{array}$ & 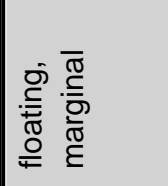 & 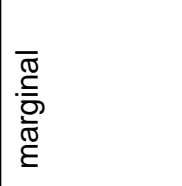 & $\begin{array}{l}\bar{\sigma} \\
. \overline{5} \\
\frac{\overline{0}}{\sigma 0} \\
\varepsilon\end{array}$ & 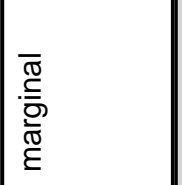 & 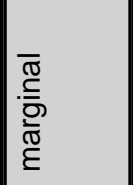 & 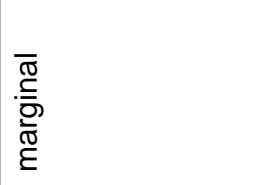 \\
\hline 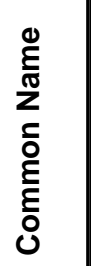 & 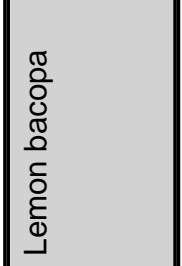 & & $\begin{array}{l}\frac{0}{\bar{T}} \\
\frac{0}{0} \\
0 \\
0 \\
\frac{0}{\pi} \\
\frac{0}{2} \\
\frac{0}{4}\end{array}$ & $\begin{array}{l}\frac{\pi}{0} \\
\frac{0}{0} \\
\frac{\pi}{\pi} \\
\frac{\pi}{0} \\
\varrho\end{array}$ & 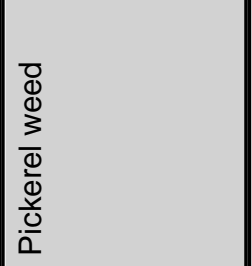 & 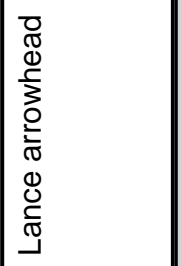 & 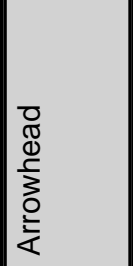 & 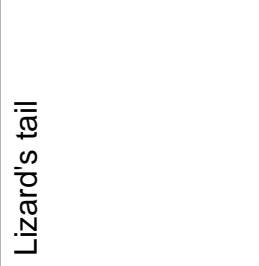 \\
\hline 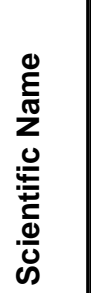 & 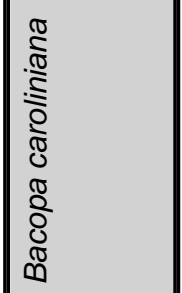 & 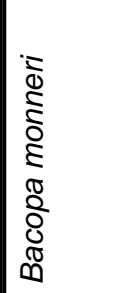 & 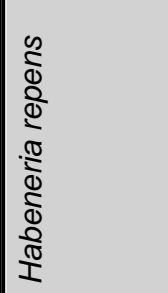 & $\begin{array}{l}\frac{0}{0} \\
\frac{\pi}{0} \\
\frac{\pi}{0} \\
\frac{0}{0}\end{array}$ & 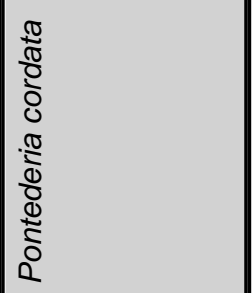 & 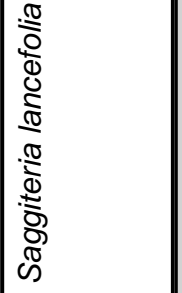 & 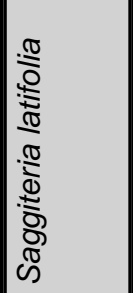 & 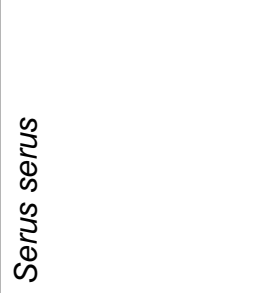 \\
\hline
\end{tabular}

